\title{
A DEMYTHOLOGISED PRAYER?
}

\author{
RELIGION, MYTH AND POETRY IN NANCY'S \\ DECONSTRUCTION OF CHRISTIANITY
}

\author{
AUKJE VAN ROODEN
}

\author{
[L]a 'prière démythifiée' [est] une des \\ formulations les plus aiguës de ce que met \\ en jeu, à mon gré tout au moins, une \\ 'déconstruction du christianisme' \\ J.-L. Nancy, La Déclosion 195
}

\section{Introduction}

In the introductory text we saw that Nancy's work on Christianity neither advocates a return to religion, nor argues for its overcoming. Instead, it tries to show in which way our modern, secular society and its so-called Christian 'roots' are in fact co-original and mutually constitutive. It is this mutual constitution that makes the Christian religion fundamentally ambiguous, even to such an extent that it is fundamentally characterised by its own deconstruction. In this article, I will focus on one of the key notions within this autodeconstructive movement of Christianity: that of prayer, or more generally, of addressing God. According to Nancy, prayer - as one of the central elements of the Christian religion - reveals how Christianity contains in its heart, or rather as its heart, the principal absence of its God and therefore the germ of its own secularisation. In this respect, the desperate exclamation 'My God, my God, why hast Thou forsaken me?' would, signify Christian prayer par excellence.

As one of the rare religious practices studied by Nancy, his analysis of prayer plays a particular role within his treatment of a deconstruction of Christianity. It elaborates a line of thought that would otherwise remain rather abstract and therefore difficult to grasp. The text in which Nancy most extensively analyses the phenomenon of prayer is 'Prière démythifiée' in La Déclosion. Not only is this text significant because of its more concrete level of analysis, but 
also because of how it tries to make sense of the question of Christianity's auto-deconstruction as a question of language. 'Prière démythifiée' firstly introduces the movement of 'religion retreating from religion' ${ }^{1}$ as a form of demythologisation, and secondly - as well as correlatively - explains it as a poetic movement, a movement that is proper to poetic practices.

In what follows, we will first examine why the Christian religion would be a form of demythologisation, as well as why Christian prayer would be an example of such demythologisation $(\$ 1)$. Secondly, we will investigate why, and in what sense, 'demythologised prayer', can be understood as a poetic practice (§2). As will become clear during the analysis, Nancy's view on the autodeconstruction of Christianity is closely bound with what he refers to as his 'ontology of touching'. It is for this reason that I will make a detour through this 'haptical' ontology in the third part of my analysis ( $\$ 3)$. In the fourth part, this detour will lead us back to the question of poetry, because poetry - in Nancy's view - will appear to be a way of touching without really touching, a way of touching the untouchable. Poetry, in other words, has to be understood as a transgressive movement, as an opening towards a beyond that can never be fully grasped ( $\$ 4)$. In the final part of the analysis, I will return to the question of demythologisation and suggest that prayer's demythologisation may perhaps also imply a mythologisation (§5).

\section{Christianity's demythologisation}

A thesis only marginally stressed in La Déclosion, though revealing one of its most essential structures, is that a deconstruction of Christianity should be understood as a form of demythologisation. Nancy notes that Christianity 'understands itself in a less and less religious manner, in the sense that a religion implies a mythology'. ${ }^{2}$ This seemingly strange expression of Christian religion increasingly understanding itself 'in a less and less religious manner', is of course a reformulation of Nancy's central thesis that Christianity is a religion transgressing itself. Insofar as 'religion implies a mythology', Christianity not only distances itself from the religious, but also from the mythological. For Nancy, the turning point is at the shift from polytheism to monotheism.

\footnotetext{
1 Using this phrase as a description of Christianity's auto-deconstructive movement, Nancy repeats Gauchet's description of Christianity as religion de la sortie de la religion. Cf. M. Gauchet, Le désenchantement du monde. Une histoire politique de la religion, Gallimard, Paris 1985, 133 sq.

2 J.-L. Nancy, La Déclosion, 57. Hereafter referred to as D.
} 
In other words, the rise of monotheism evoked a retreat from the religious, as well as from the mythological.

As mainly developed in the more programmatic texts of La Déclosion ('Déconstruction du christianisme', 'Déconstruction du monothéisme' and 'Athéisme et monothéisme') the rise of Christian monotheism is in Nancy's view not so much characterised by a single God as opposed to the multiple gods of polytheism, but rather by the presence of this God and, consequently, the way in which he is represented. Polytheistic religions affirm the 'effective presence' of gods who inhabit the world and who organise it 'by means of the totality of its myths and its rites' (D, 55). This worldview is mytho-logical because it binds logos with muthos, or as Nancy already advanced in La communauté désoeuvrée (1990), because it understands the world as 'structuring itself in logos'. ${ }^{3}$ The order and sense of the polytheistic world are thus given - in the sense of both present and offered in logos.

With the rise of monotheism, however, God is no longer present in the world. Instead, he is seen as transcendent, because he has retreated himself from the world by virtue of the very act of creating it. As a result of his retreat, the monotheistic God resists mythological, immediate presentation. This impossibility of the Christian God to present himself and to be represented at the same time entails his uniqueness and the possibility of his total disappearance. This is the reason why demythologisation is one of the main traits of the autodeconstructive character of Christianity, as Nancy shows 'Déconstruction du monotheisme' (D, 57). As a result, it can be said that religion's demythologisation not only cleared the way for Christianity, but also for atheism. Once again it follows for Nancy that Christianity and secular modernity are not to be viewed as historically successive, but rather as worldviews that are 'contemporary and correlative' (D, 39).

In a way, Christian prayer is a direct result of the absenting of God. Addressed to that which is most hidden, without the guarantee of being heard, and often even pronounced in silence, prayer is simultaneously the evocation of God and the affirmation of his absence. It is no surprise then that the notion of 'demythologised prayer' is one of the ways in which Nancy examines the coincidence of religion and its transgression. As Nancy indicates at the beginning of his text, the phrase 'demythologised prayer'

3 J.-L. Nancy, 'Le mythe interrompu', La communauté désæuvrée, Christian Bourgeois, Paris 1999 [1986], 125. 
was originally used by Adorno as a definition of music. For Adorno, music is a

entmythologisiertes Gebet, befreit von der Magie des Einwirkens; der wie immer auch vergebliche menschliche Versuch, den Namen selber zu nennen, nicht Bedeutungen mitzuteilen. ${ }^{4}$

In his commentary on Adorno's phrase, Nancy nevertheless endows these words with a much broader meaning, indicating that they form an answer to the pressing and ultimately modern question of

[c]omment donner sens, ou, plus simplement, comment donner cours - en s'abstenant de faire sens - non pas à la religion péniblement réanimée, mais à ces 'reliques' (comme Deguy aime à dire, mettant aussitôt en jeu et en émoi le sens d'un terme religieux) que la religion éteinte nous abandonne - telle que la prière, la foi, le nom de 'Dieu' lui-même et quelques autres témoignes d'une irréductibilité de langage. (D, 190:1n)

In this commentary, which strangely enough has been put in a footnote, Nancy parenthetically advances several very important theses in relation to his view on religion. First of all, he dismisses the so-called 'revival of religion' - la religion péniblement réanimée - as the central question of modernity, as we saw earlier. Secondly, some of the most essential elements of the Christian religion, i.e. prayer, the name of God, and even faith itself, are characterised by Nancy as 'relics'. Although doing so may seem cliché, it actually provides a very accurate description of Nancy's understanding of Christianity's autodeconstructive nature. Its nature is mainly a process of exhaustion and selfemptying of significant content, leaving no more than a purified belief in an absent divinity. In a sense, Christianity becomes its own relic, i.e. that which remains when the divine itself is absent, éteint.

Thirdly and finally, Nancy relates the relic, this deconstructive nature of religion to language, or to be more precise, to an 'irreducibility', an obstinacy of language. We could say that, due to the absenting of God, language itself has also become a relic. As a result, holy names are not only lacking, as was noticed by Hölderlin, but at the same time they also remain and offer a certain

\footnotetext{
4 Th. Adorno, 'Fragmente über Musik und Sprache', Quasi una fantasia. Musikalische Schriften II, Gesammelte Schriften Band 16, Suhrkamp Verlag, Frankfurt a/M 1978, 252. My emphasis, AvR. This phrase of Adorno had been cited by the poet Michel Deguy in his Sans retour (2004), which in turn is cited by Nancy in 'Prière démythifiée', La Déclosion, 189. The French translation reads: 'prière démythifiée, délivrée de la magie de l'effet, représente la tentative humaine, si vaine soit-elle, d'énoncer le Nom lui-même au lieu de communiquer des significations.' Deguy's emphasis.
} 
resistance. The retreat of God has left us with nothing but his name, a name of which the referent is principally absent or which perhaps indicates the absence as such. One could therefore posit that the name of God corresponds to the lyrical figure of the apostrophe, since it only momentarily brings to presence what is principally out of reach. Thus God can perhaps only be addressed in a lyrical manner, or as Adorno also states, by simply calling his name instead of providing it with meaning. ${ }^{5}$

Nancy's view on Christianity's demythologisation requires a revision of the concept of meaning or sense which follows from his repeated characterisation of Christianity as a form of 'absentheism' (cf. D, 32). With this notion, Nancy points out that the Christian God is a 'God of which the absence is properly its divinity' ( $D, 56)$. In taking this position, Nancy explicitly refers to Maurice Blanchot's notion of a 'sens absent', as being a sense 'that makes sense in and by its own absenting' (D, 130). ${ }^{6}$ Sense is thus not simply absent as it is in nihilism, just as God is not simply absent as he is in atheism, but it is rather fleeing, retreating, always still to come. In its affirmation of a God as an organising principle that is beyond the world, Christianity presupposes a world that in its opening towards this beyond is itself deprived of a given sense. It is precisely this presupposition, the presupposition that the absence of sense itself is divine, that forms the central aspect of Christianity's auto-deconstruction.

The practice of praying plays such a significant role within this autodeconstruction, because it is a practice that performs this deprivation of sense. As Nancy writes, it is

ni une catégorie ni une opération particulière du langage, destinée à quelque fin spécifique de signification et de transmission, mais indique au contraire un geste, une posture et une postulation selon lesquels le langage est tendu à sa limite, sur sa limite qu'il excède tout en se tenant sur elle. (D, 192. My emphasis, AvR)

In other words, prayer is the practice in which the impossibility of immediate presentation itself is presented. Given the structure of prayer, the notion of

5 One could perhaps say that the exclamation 'My God, my God, why hast Thou forsaken me?' is the lyrical form par excellence, of which all verses such as ' $\mathrm{O}$ wild west wind, thou breath of autumns being' (Ode to the West Wind, Percy Shelley) and 'Ô toi qui, comme une ombre à la trace éphémère!'('Je te donne ces vers', Ch. Baudelaire) are derivatives. This is not the place for a closer examination of this lyrical figure of the apostrophe or 'vocative', but Nancy's association of religion and poetry could also be explained in terms of this figure.

6 By referring to Blanchot's notion, Nancy not only explains his view on sense, but once again makes an interesting connection between the Christian religion and literature. Writing, as Nancy states with reference to Blanchot, is an exposition to the absent sense that binds together monotheism and atheism. 
'demythologised prayer' is thus strictly speaking tautological, since demythologisation cannot but ask for the kind of emptied linguistic 'gesture' that is prayer. Conversely, prayer has to be understood as a use of language that already does away with myth. Or as Nancy states rather enigmatically at the beginning of his text: " "prière démythifiée" ne serait un paradoxe qu'aussi longtemps qu'on n'aurait pas dépouillé la "prière" de son caractère de... prière, précisément.'(D, 190) Just as Christianity is a 'religion retreating from religion', Christian prayer would thus be 'a prayer deprived of its character as prayer', or, perhaps more accurately, a prayer that deprives itself of its own character as prayer.

\section{Prayer as a poetic gesture}

Rather than a means of communication or transfer of a certain message, demythologised prayer should thus be understood as a certain gesture of language. The gesture of prayer is a linguistic gesture that aims to break through the communicative function of language. It is a gesture addressed to an unknown addressee, of whom it is uncertain that he will perceive it. With good reason, Nancy, as well as Deguy before him, refer to Adorno's fragment on music, since music has always been considered as a form of art that on the one hand is closest to language, but on the other hand removed the furthest from the regime of representation. Nevertheless, Nancy hastens to say that the music Adorno has in mind is that of the opera, i.e. music that is sung. What is significant, however, is that it is a use of language whose meaning has been subordinated to the gesture, sound and rituality of the utterance.

The fact that prayer complicates the representational function of language, results in a destabilisation of the opposition generally affirmed between logos and muthos. Whereas logos and muthos were inextricably bound within the polytheistic worldview, in the sense that the world was supposed to be immediately structured by myths, we saw that monotheism excludes the possibility of such an immediate structuring. The very source of modernity lies precisely in the separation of logos and muthos, i.e. in the alleged freeing of the logos of divine structuring. Because of his retreat from the world, the monotheistic God could not be addressed by means of myths, but only through the gesture of prayer. A gesture which, as Nancy points out in 'Prière démythifiée', is that of a 'logos without muthos' (D 194).

However, Nancy does not want to affirm the opposition between logos and muthos, but instead seeks to destabilise it. He therefore continues, in a somewhat unclear and hasty manner, to claim that strictly speaking, this "logos 
without muthos' is also a 'muthos without muthos', taking into account the original meaning of the word muthos, which according to Nancy merely signifies 'the spoken word' or 'speech' (D, 194). Although one could wonder whether Nancy's explanation of muthos is as obvious as he considers it to be, it is clear that he discerns a kind of auto-deconstructive movement within muthos itself. In other words, muthos is not so much replaced by logos with the rise of monotheism, but has rather retreated from itself. Or to be more precise: $\log o s$ and muthos seem to be mutually constitutive in the sense that logos is nothing but muthos' retreat from itself. ${ }^{7}$

Far from playing a linguistic game, Nancy is looking for the unchallengeable core of prayer as a linguistic gesture towards an addressee that is not only outside of the one who prays, but also outside of language itself. It is important to understand that this linguistic gesture is not a complete silencing of language, nor a haphazardly saying of no matter what. It is rather a form of language that is 'presque étouffé, en tout cas detimbré, retiré aux sonorités pleines de la signification et à la possibilité d'une nomination.' (D, 194) This phrase - a poetic phrase par excellence with its stirring rhythm and repetitive end rhyme - results in the ultimate conclusion of this line of thought and one of the central theses of Nancy's text, namely that prayer is 'something like poetry': 'quelque chose de la poésie' (D, 194, my emphasis, AvR). This little remark is nothing more than a hint, a gesture, that - at least in 'Prière démythifiée' - has hardly been further elaborated. Nevertheless, it is precisely this hint that we will take as a point of departure in what follows. We will examine what kind of poetry is meant in the description of demythologised prayer as 'something like poetry' and the implications of this description for Nancy's view on religion in general.

As mentioned, the poetry Nancy hints at has to be viewed as an emptied language, a suspense of communication in the form of an addressing without addressee. In other words, prayer is a meaningless, not to say idle, way of speaking into the void, addressed to an addressee that cannot be addressed. Yet it is precisely this speaking into the void that creates an opening, an opening of language to that which is beyond language. What this opening consists of becomes extremely clear when the function of prayer is deprived of its

\footnotetext{
7 Nancy came back to this question of muthos, in an 'afterword' to Lacoue-Labarthe's L' "Allégorie" (Galilée, Paris 2006). Here, Nancy distinguishes between mythology and myth, thereby calling for a 'myth without mythology', which corresponds exactly to the auto-deconstructive movement described above: 'Mythe tenu à distance pour mieux laisser venir et revenir cette ouverture d'un muthos.' (162)
} 
religious connotations and is examined in its daily use. First and foremost, this daily use is a French one, but indirectly also recognisable in other languages. It is contained in expressions such as 'je vous prie d'agréer...' or 'prière de répondre', of which a rather literal but unusual English translation would be 'I pray you to accept...' and 'Please (I pray you to) respond'. This ordinary form of address, implicitly accompanying every request to another person, is in a sense the condition of possibility for communication, a letting-be of the addressee and therefore as it were the 'relic' of the request made to God by means of prayer (cf. D, 196).

Echoing Heidegger's view on Dichtung, Nancy seems to proclaim that this poetic language is a kind of Ursprache, an original opening of language that enables the world to appear:

Essentiellement, le dire [the original saying, like that of prayer, AvR] s'emploie à laisser le réel - res, la chose - se réaliser, c'est-à-dire être ce qu'il est et surtout être qu'il est. Ce 'laisser être' est son office. (D, 197)

In other words, the poetic character of prayer denotes that prayer is just a saying while in fact nothing is said. Nothing - no thing, or rather nothing but the thing itself, i.e.: being, res, la chose. In linguistic theory, this kind of saying would be called performative, which corresponds to a certain state of affairs through the single fact of being uttered. As we saw earlier, this state of affairs is first of all an opening towards a beyond, a call - like the lyrical ' $\mathrm{O}$ ' - that functions as a portal, providing access within the domain of language, but an access that is blocked at the threshold.

It can be said that Nancy, by relating demythologisation to 'something like poetry', supports the interpretation given by Walter Benjamin of the poetry written by Friedrich Hölderlin. Contrary to Heidegger's well-known and influential interpretation of Hölderlin's poetry, Benjamin tried to show that this poetry is essentially demythologising. ${ }^{8}$ According to Benjamin, Hölderlin's poems are not a mythological representation of the divine, but - on the contrary - should be considered on their own, literally. In Benjamin's view, Hölderlin's poems '[stehen] im eignen geistigen Leben, in dem nun die

\footnotetext{
${ }^{8}$ To be more precise, in 'Zwei Gedichte von Friedrich Hölderlin' Benjamin actually claims that Hölderlin's poetry is mythical rather that mythological. What Benjamin understands by mythical is nevertheless analogous to what Nancy declared to be demythological. Furthermore, in the text already mentioned in note 7, Nancy equally distinguishes between the mythological and the mythical, nonetheless without referring to Benjamin's analysis. Cf. J.-L. Nancy, 'Un commencement', Post-face to Ph. Lacoue-Labarthe, L'«Allégorie», Galilée, Paris 2006.
} 
Nüchternheit erlaubt, geboten, ist, weil es in sich heilig ist, jenseits aller Erhebung im Erhabnen steht.' ${ }^{9}$ Hölderlin's poems first of all express their own being-a-poem. In short, Hölderlin's poetry is demythologising, because its saying is not the foundation or justification of a world, nor the symbolic representation of it, but just an expression of its own saying.

Paradoxically, a poem being nothing else than an expression of itself as a poem, is sacred for Hölderlin and exactly for that reason. Sacredness means precisely not to represent divine figures. On the contrary, it means to be self-reflexive. Consequently, calling this self-reflexivity 'sober', Hölderlin characterises his own poetry as an expression of das heilig nüchterne - sacred sobriety. This sacred sobriety of Hölderlin's demythologised poetry articulates the same apparently contradictory logic as Nancy's demythologised prayer. Like Nancy's demythologised prayer, the sacred sobriety that Hölderlin wanted to express with his poems is not a contradiction but a tautology. After all, it is precisely the demythologisation of this poetry that makes it sacred.

Although it may initially seem confusing to relate the notion of demythologisation to that of the sacred, the latter actually appears as a key notion within Nancy's analysis of Christianity's auto-deconstruction. It is true that the notion of the sacred is relatively absent in La Déclosion, but it is of major importance in some of Nancy's earlier texts, which can retrospectively be considered as preliminary explorations of a deconstruction of Christianity. Again, Nancy's treatment of this notion leads to a deliberate displacement of its current meaning. Whereas the critical rejection of religion has over the years generally been formulated in terms of a $d e$-sacralisation, thereby equating religion and sacrality, Nancy instead actually uses the notion of the sacred to refer to the secular - or sober, in Hölderlin's terms - aspect of religion. In Nancy's view, the sacred is not equal to the religious, but is rather one of the indications that religion necessarily surpasses itself.

In this case, it may perhaps be revealing to explore a distinction that I believe to be crucial, one that Nancy makes on several occasions, namely that between the religious and the sacred. One of the places where Nancy underlines this distinction in 'L'image - le distinct' (Au fond des images 2003), a text that appeared two years earlier than 'Prière démythifiée'. On the one hand, religion - which literally means 'binding' - refers to realizing and maintaining a bond

\footnotetext{
9 W. Benjamin, 'Zwei Gedichte von Friedrich Hölderlin: "Dichtermut" und "Blödigkeit", Gesammelte Schriften II.1, Suhrkamp, Frankfurt a/M 1977, 125. My emphasis, AvR. Originally published in Schriften I, Suhrkamp, Frankfurt a/M 1955, 375-400.
} 
with the divine, the supernatural or the Other. ${ }^{10}$ On the other hand, the sacred indicates precisely the impossibility of such a bond, since that which one wants to relate to retreats from presence. Whereas the religious bond implies homogeneity and continuity, the sacred is by definition unattainable and incommensurable. Religion and the sacred are thus opposed 'as the bond is opposed to the cut' (FI, 11). As a result, the sacred is essentially non-religious. Although Nancy has always remained faithful to the underlying structure of this distinction, the opposition of the religious and the sacred must not be maintained too strictly. The main reason for doing so is that Nancy uses another set of terms in other contexts, or as is for instance the case in 'Prière démythifiée', places the distinction at the heart of one term only - the religious - thereby underlining once more the auto-deconstructive character of religion. In this case, the 'religious' is simultaneously explained by means of both its possible etymological sources, namely 'binding' (religare) as well as 'observing' (religere) or even 'addressing' or 'adoring', as explained in 'Prière démythifiée':

L'ad-oration, c'est littéralement l'adresse de la parole. Mais, essentiellement, cette adresse est à l'autre de la parole: à la res. Et si l'adoration des idoles constitue, à travers notre tradition, au-delà même de la religion, la pierre de touche [...] c'est bien parce que l' «idole» représente $[\ldots]$ la chose sans présence «réelle» et qui n'entend pas, en vérité, la parole que l'adolâtre lui adresse. $(\mathrm{D}, 197)^{11}$

The distinction that Nancy makes between the religious and the sacred, or between religion as binding and religion as addressing what is out of reach, can be broadened to include another distinction he makes with respect to Christianity's auto-deconstruction, namely the distinction between faith (foi) on the one hand and belief (croyance) on the other. ${ }^{12}$ In this context, 'belief' belongs

10 Although some would deny that a thinking of the Other can be religious in this sense, because the Other is precisely what cannot be attained, Nancy claims in 'L'Image - le distinct' that such a notion of the Other is often related to a thinking of sacrifice, and that sacrifice has to be understood as the constitution of a bond with the Other. According to Nancy, a sacrifice is therefore a making religious of the sacred. On the contrary, the sacred cannot be sacrificed. Cf. J.-L. Nancy, Au fond des images, Galilée, Paris 2003, 14: 'Dans le lexique religieux du sacré, ce franchissement [du distinct] constituait le sacrifice ou la transgression: comme je l'ai déjà dit, le sacrifice est la transgression légitimée. Il consiste à faire sacré (à constater), c'est à dire à faire ce qui, en droit, ne peut pas être fait.' Hereafter referred to as FI.

11 The meaning of religere has been extensively addressed by Nancy in a lecture entitled 'Une religion civil', given at Espace Marx, Paris, 6 ${ }^{\text {th }}$ of January 2005.

12 Cf. J.-L. Nancy, 'L'Image, le distinct', Au fond des images; J.-L. Nancy, Au ciel et sur la terre. Petite conférence sur Dieu, Bayard, Paris 2004 et J.-L. Nancy, La Déclosion, 24, 39, 76sq, 151 and especially 220 sq. 
to the category of what has been called the religious, as opposed to the sacred..$^{13}$ It refers to those aspects of religion that present the divine, thereby allowing a bond to be established with it, such as through the use of icons or by performing cultic rituals and sacrifices. 'Faith', on the other hand, belongs to the category of what has been called the sacred and which is required in a situation where the divine has retreated. Since the Christian God is absent in principle, Christianity is a faith in this absence, a faith in nothing, or as Nancy formulates it in La Déclosion 'a faithfulness to faithfulness itself' (D, 223):

[L]a foi chrétienne se distingue précisément et absolument de toute croyance. Elle est une catégorie sui generis qui n'est pas, comme la croyance, un manque de..., un défaut de..., qui n'est pas attente de..., mais qui est, par elle-même, fidélité, confiance et ouverture de la possibilité de ce à quoi elle est confiance. $(\mathrm{D}, 221)$

Instead of something that can be confirmed or supported, faith is therefore above all a loyalty, a loyalty in the absence of a guarantee.

\section{An ontology of touching}

Although this is not the case in 'Prière démythifiée', the difference between faith and belief (which is one of the crucial steps in Nancy's deconstruction of Christianity), can be explained in terms of the tactile, i.e. in terms of touch and touching. Whereas 'belief' enables one to reach the divine - e.g. to touch and seize it within a mythological representation - 'faith' is a loyalty to that which cannot and should not be touched, to that which always remains at a distance. Since the Christian God is principally absent, he is always beyond reach and in that sense principally untouchable. As will become clear below, this does not mean that the Christian God is invulnerable. For Nancy, the possibility or impossibility of touch is not an ethical issue, but rather an ontological one. A translation of Nancy's view on religion in terms of touch and touching may therefore be helpful, since it would clarify their role within the larger context of Nancy's oeuvre. Simplifying matters a little, one could say that this oeuvre as a whole aims to advance a new ontology, an ontology of touching. As can be seen in several of his texts, Nancy understands the sense of touch on a very concrete, but also very abstract level. On the one hand, touching is the haptic contact between two surfaces at a specific time and place, i.e. a concrete

13 Cf. J.-L. Nancy, 'L'Image - le distinct', Au fond des images, 11.: 'La religion ne l'est pas, de soi, ordonnée au sacré. (Elle ne l'est pas non plus à la foi, qui est encore une autre catégorie).' 
sensible experience of the body. On the other hand, however, touch is the most primal sense, since it is the condition of possibility for sensibility as such:

The indifference of the zones [of the senses, AvR] is exposed by the primacy of touch. [...] The touch is nothing other than the touch or stroke of sense altogether and of all senses. The touch is their sensuality as such. (Translation modified) ${ }^{14}$

The moment when two surfaces scratch each other, when they touch each other and are touched, is the moment when sensuality as such arises. Seeing, hearing, tasting - one should even say existing - is only possible if one has touched upon another or several other surfaces. This is the reason why touch is not just a transcendental, but also an ontological movement for Nancy. In other words, touching manifests nothing less than the opening of a world and therefore the emergence of sensibility. It is 'l'espacement des temps et des lieux, l'espacement comme tel rend possible la présence et son toucher. ${ }^{15}$ Conversely, the opening of the world has to be understood as a transcendental and ontological touching.

The new ontology that Nancy tries to advance is also a kind of materialist ontology that has to be understood in terms of touch. As Derrida extensively shows in Le toucher, Jean-Luc Nancy (2000), this ontology to a large extent elaborates on the phenomenological tradition of Husserl and Merleau-Ponty. Nevertheless, Nancy at the same time severely criticises this tradition, stressing the fact that it failed to overcome the traditional idea of an interiority as opposed to an exteriority, i.e. the idea of a 'corps propre'. Contrary to this, Nancy, tries to underline not only the fact that there is a fundamental and constitutive bond between the interiority and exteriority of a body, between a body and its outside, but also that the body itself is already outside of itself, different to itself - an ex-position towards the outside: 'Un corps, c'est de l'extension. Un corps, c'est de l'exposition. Non seulement qu'un corps est exposé, mais un corps, cela consiste à s'exposer.'16 Therefore the body is thus not closed in itself, nor is it something that can be appropriated. Instead it is, something that is always already open, opened by, and towards, others and for that reason always already 'infected' by them.

14 J.-L. Nancy, The Muses, Stanford University Press, 1996, 16/7. Originally: 'L'indifférence des zones s'expose par le primat du toucher. [...] Le toucher n'est autre chose que la touche du sens tout entier, et de tous les sens. Il est leur sensualité comme telle.' 'Pourquoi y a-t-il plusieurs arts, et non pas un seul?', Les Muses, Galilée, Paris 2001 [1994] 35.

15 J.-L. Nancy, 'Le calcul du poète', Des lieux divins suivi de Calcul du poète, Trans-EuropRepress, 1997, 72. Hereafter referred to as CP.

16 J.-L. Nancy, Corpus, Métaillé, Paris 1992, 109. 
Although this 'infectious' structure of touching seems to contradict our daily experience, we should remember that this experience itself has a double character, as is extensively shown in the work of Merleau-Ponty. The sense of touching always manifests itself in a double or paradoxical way, because it simultaneously provides the experience of sensing and that of sensing one's own sensibility. Nancy stresses that the one that senses and the one that is sensed never entirely coincide and that as a result every contact always presupposes a certain distance, a differance of a person with him-/herself. This is why Nancy claims that 'Le toucher est l'intervalle et l'hétérogénéité du toucher. Le toucher est la distance proxime [...]: la proximité du distant, l'approximation de l'intime. '17 The sense of touch thus manifests itself according to a paradoxical logic that simultaneously articulates the proximity and the distance between what touches and what is touched.

The profound entwinement of proximity and distance is equally explained by Nancy through the notion 'le distinct'. This ambiguous notion, simultaneously referring to what is distant and different, as well as to what is very clear, indicates precisely that which remains at a distance when it touches or is being touched:

Il [le distinct, AvR] est ce qu'on ne peut pas toucher (ou seulement d'un toucher sans contact). [...] Le distinct, selon l'étymologie, c'est cela qui est séparé par des marques (le mot renvoie à stigma, marque au fer, piqûre, incision, tatouage): cela qu'un trait retire et tient à l'écart, en le marquant aussi de ce retrait. (FI, 12)

The distinct can thus only be touched, be reached, 'without contact', i.e. without being grasped, being appropriated. Nancy proceeds his explanation of the distinct by underlining that it can only be touched without contact, not because one does not have the right, nor the means, but because the distinct no longer belongs to the order of touch. What is distinct is not so much untouchable, but rather inaccessible. ${ }^{18}$

It is not without reason that Nancy mentions the stigma as the etymological source of the word 'distinct'. The stigma of Jesus Christ can be seen as the

17 J.-L. Nancy, 'Pourquoi y a-t-il plusieurs arts, et non pas un seul?', Les Muses, 35. My emphasis, AvR.

18 Cf. J.-L. Nancy, 'L'image - le distinct', Au fond des images, 12: ‘[C]e n'est pas qu'on n'en a pas le droit, et ce n'est pas non plus qu'un manque de moyens, mais c'est que le trait distinctif sépare ce qui n'est plus de l'ordre du toucher, pas exactement, donc, un intouchable, mais plutôt un impalpable.' From this remark, one can once more see that the distinct is first of all not an ethical category for Nancy, but an ontological or transcendental one. 
mark or the sign of the distinct par excellence: God. Whereas religion understood as 'belief', of which the polytheistic religions are the prototype, would be an example of grasping the divine, i.e. of a touching with contact, religious 'faith' as Nancy characterises Christianity, would thus be a touching of (or being touched by) God without contact. The first one implies that one appropriates God, that one seizes him within a representational regime. As we saw earlier, however, the Christian God is always beyond reach, not because he is invulnerable, but - as should be clear by now - because he is inaccessible. $\mathrm{He}$ is inaccessible, precisely because he is the condition of possibility for access as such, i.e. of the possibility of sensuality. In other words, God is the name of what Nancy refers to as the transcendental and ontological opening of the world.

\section{Poetry as a way of touching the untouchable}

The central question of the text 'Prière démythifiée' can now be reformulated as the question of how to address that which is beyond reach. How to reach, by means of prayer, the Distinct One, God? Once again the answer to this question has to be sought in art. Similarly, and equally cautious as the hint that a demythologised prayer would be 'something like poetry', Nancy writes that the distinct would belong to the domain of art: 'En conséquence, ma question première et dernière sera: est-ce que un tel trait distinctif n'est pas toujours l'affaire de l'art?' (FI, 12) Moreover, while distinguishing once more between the religious (as binding) on the one hand, and the sacred (as the impossibility of a bond) on the other, Nancy stresses the relationship between the sacred and art:

Là [there where religion ends, AvR] commencent la distinction et le maintien de la distance et de la distinction 'sacrée'. C'est là peut-être, que l'art a toujours commencé, non dans la religion (qu'il y fut ou non associé), mais à l'écart. (FI, 19, my emphasis, AvR)

The hint that the sacred or the distinct - the distinct that is principally sacred - has to be addressed by means of art is strengthened by the fact that Nancy, in one of his most important texts dealing with the poetry of Hölderlin, refers to this poetry as an articulation of the distinct. Although the distinct may perhaps be inaccessible, it can still be in addressed in poetry or in something like poetry. As we saw earlier, it is the sacredly sober poetry of Hölderlin that appears to be the exemplary way of touching without contact.

Let us therefore examine more closely this poetic touching. Nancy describes Hölderlin's poems - curiously enough by making use of the vocabulary of the 
visible - as a touching that preserves the difference between that which touches and that which is being touched: 'le regard touchant isole le point du contact. Et il l'isole de deux manières: d'une part, il touche en un seul point, et d'autre part, il laisse face à face le touchant et le touché.' $(\mathrm{CP}, 67)$ Moreover, it does so by an exact calculation of the distance between the two: 'Le point de contact [...] c'est exactitude opportune du calcul qui livre le sens, ou qui livre au sens, en suspendant le cours ininterrompu du sens.' (CP, 66) This calculation appears to be the most important element of Hölderlin's poetry, since it places the distinct at a proximate distance. But how can poetry be calculated or calculative?

First of all, it is not by saying no matter what, n'importe quoi. As Nancy points out in 'Prière démythifiée', poetry and prayer are alike in this respect. In reply to asking himself one of the most pressing questions concerning prayer, namely 'What should one say?', he writes:

Une réponse serait qu'elle [i.e. prayer, AvR] dira n'importe quoi pourvu qu'elle dise, mais qu'elle dise, à tout le moins, selon l'exigence ou selon le désir du dire: celui de dire la chose. En ce point précis, la pire confusion est possible: l'essence du dire peut tourner en 'dire pour dire'. (D, 196, my emphasis, AvR)

Just as poetry has to be exact in order not to relapse into l'art pour l'art, prayer has to be an exact saying in order not to relapse into a mere dire pour dire. This is the reason why poetic saying is - as Nancy states in Calcul du poète 'le lieu d'un dire exact: point de passage' (D, 59, my emphasis, AvR). The explanation of this exact saying is not without importance. It is here that both meanings of the sense of touch, i.e. both its narrow and broad one, come together. According to Nancy, only a concrete touch between two specific surfaces can enable an opening of sense. If exactitude is lacking, then there cannot be an opening.

Nevertheless, and this is the whole difficulty, since the distinct - or God - is inaccessible, as we saw earlier, it is also beyond measure. As a result, the poetic calculation can only be based on coincidence. ${ }^{19}$ It is very difficult to clarify this cautious poetic approach of the sacred. In this respect, a comparison with the early romantic notion of Witz might be illuminating. This notion, in particular as coined by Fr. Schlegel and Novalis, refers to a 'principle of affinities'

19 In trying to understand the nancian notion of touch, Derrida explains it as a "mediated coincidence', in contrast to a long philosophical tradition stemming from Aristotle understanding the touch as an 'immediate coincidence'. J. Derrida, On Touching - Jean-Luc Nancy, Stanford University Press, 2005, 144. 
(Novalis), to a grasping, within a single glance, the world in all its heterogeneity. This Witz, this stroke of lighting in which there is a simultaneous combination and dissolution of heterogeneous elements, was not so much a way to unveil the absolute, but moreover of producing it by a certain arrangement of poetic elements, as is the case with the tragic caesura. It is, so to speak, a way of 'arranging coincidence', arranging a coincidence that enables to be touched. Indeed Nancy refers to the romantic Witz while explaining the paradoxical logic of the mythological prayer. Because it expresses the secular aspect or dimension of religious practice, prayer is part of a deconstructive logic that Nancy describes as 'la puissance de l'oxymore' (D, 192). ${ }^{20}$

Although Nancy does not explicitly distinguish the logic of the 'poetic prayer' from the romantic Witz, there nevertheless remains an important difference. Whereas the romantic Witz is a singular, unique stroke, Nancy's tactile touch is repetitive. In other words, there is no single moment where everything falls into the right place once and for all, but an infinite series of events, a series that is articulated, not by the poetic caesura, but by the metre. Because of this repetition, there is not so much a fusion of different elements, but rather a continuous interruption of such fusion. As Nancy understands it, the poetic arrangement is therefore not a coincidence of elements, but rather their coexistence, the being together of what remains fundamentally different. As a result, the poetic metre, as an expression of the repetitive collision of coexisting elements, enables measurement of the distance to that which has to stay at a distance. Once again, poetry obtains a religious connotation:

La mètre mesure cela même, ce 'vestige des dieux enfuis' (Hölderlin, 814) qui n'est ni la pure perte, ni le signe renvoyant au loin, mais la trace du passage [...] dont le contact s'écarte en le touchant. $(\mathrm{CP}, 74)$

The Gods (or God) that have fled or retreated do not mark a total loss, nor do they leave a sign. They rather mark a passage, an opening. In other words, due to this continuous interruption by the poetic metre, the poem resist a fixed meaning and instead articulates the emergence of meaning itself.

Because of the incessant interruption, the meaning of the poem is suspended, over and over again. At the same time, however, this interruption results in an endless stream of different meanings, because the poetic fragments can be combined in different ways. In sum, the poem does not really present something

20 Apart from the romantic Witz, the Gnostic coincidentia oppositorum and the derridian aporia are, among others, also placed under this heading. 
meaningful, except for this interruption and opening of meaning itself. What is presented by poetry is thus not so much a well-formed work, but rather a formative force, a formation. Poetry, as Deleuze would say, is the stuttering of language that in its stagnation precisely shows its working all the better. This is also the reason why Nancy prefers to use the Greek word poiesis instead of the terms 'literature' or 'poetry'. Rather than to referring to a finished and fixed product, poiesis refers to a constant creative production. Since this poiesis, this ontological 'production' of reality, is principally marked by interruption, by the impossibility of being grasped, it is in fact - as Nancy states sacred.

\section{A demythologised prayer?}

It will be clear that Nancy ascribes such an important role to poetry because - following Heidegger's Dichtung and Hölderlin's sacred sober poetry - he understands it as an ontological gesture. 'Ontology', as Nancy paraphrases it in Corpus, 'turns out to be writing'. Using a vocabulary that should be familiar by now, and which actually presents a wonderful summary of our analysis so far, Nancy proceeds:

'Écrire' veut dire: non la monstration, ni la démonstration d'une signification, mais un geste pour toucher au sens. Un toucher, un tact qui est comme un adresse: celui qui écrit ne touche pas sur le mode de la saisie, de la prise en main, mail il touche sur le mode de s'adresser, de s'envoyer à la touche d'un dehors, d'un dérobé, d'un écarté, d'un espacé. ${ }^{21}$

As Nancy points out, poetry has to be conceived of as ontological, because it is a poiesis, a making of the word, of reality. In that sense, poetry is the religious praxis par excellence, equal to the divine creation of the world. In sum, poetry is not religious because it provides an adequate presentation of the divine, but because the poetic saying - as saying - is itself divine, heilig. Conversely, one could say that reality, in its turn, is poetic. This thesis has already been advanced by Nancy in his La communauté désoeuvrée (1990): 'l'être en commun $[\ldots]$ est littéraire'. 22 The new ontology Nancy proposes is thus a poetic ontology in which being is first of all understood as the reciprocal exposition of touching beings. A being cannot but articulate itself in a poetic way

21 J.-L. Nancy, Corpus, 19.

22 J.-L. Nancy, 'La communauté désœuvrée', La communauté désœuvrée, 160. My emphasis, AvR. Because Nancy uses the term 'poetry' in its etymological sense of poiesis, there is, for Nancy, no fundamental difference between poetry and literature. 
or to be more precise, as poetry, because poetry is the inscription of this exposition.

Above we roughly sketched Nancy's project of a deconstruction of Christianity, pointing out that Christianity, or monotheism in general, is a religion that according to Nancy also deconstructs its own religiosity. The heart of Christianity's auto-deconstruction has to be found in the fact that the Christian God is not present in the world but principally absent, as well as in the fact that this absence as such is considered as divine. The text 'Prière démythifiée' shows the way in which this auto-deconstructive character is laid bare within the practice of praying. As we have seen, prayer is in principle demythologised, because it is addressed towards a God that resists immediate presentation. As Nancy casually mentioned, such a linguistic addressing without representation, such an emptied linguistic gesture, can perhaps be understood as poetic. Analysing some of Nancy's texts on poetry, I showed that poetic saying in Nancy's view indeed responds to how the Christian God has to be addressed. As we have seen, this addressing is an exhaustion of language that creates an opening in which one can address and be addressed.

In this last part, we will take Nancy's view a little bit further by asking not so much why praying would be poetic and why prayer would be a poiesis of the world, but by asking how this poetic prayer can be affirmed as such. In doing so, we will reiterate one of the main questions posed by Nancy in 'Prière démythifiée', namely 'Comment une prière démythifiée peut-elle être prière?' (D, 190) In his text, Nancy has mainly focused on explaining, firstly, why prayer would be an example of religion's own demythologisation and, secondly, why such prayer would be an exemplary way of addressing the Christian God. This explanation, however, serves in fact only as an answer to a second question that in Nancy's view is a 'more demanding' reformulation of the first one, namely: 'Comment une prière démythifiée peut-elle prier?' In my view, however, the crucial but largely unanswered question is how one can affirm prayer as prayer. Considering that praying is something like poetry, how can one still affirm that one is praying instead of citing a poem?

Although I am aware of the fact that Nancy's goal was actually to show that both prayer and poetry are one and the same praxis, i.e. making a gesture of ex-position, Nancy nevertheless points out the difference between the two at the end of his text:

[L]a prière - en cela précisément différente du poème aussi bien que du discours, et même si le poème tend aussi vers elle - se caractérise avant tout comme une parole qui accompagne un acte. On prie avec les actions du culte, on prie avec un rituel de prière [...]. (D, 190, my emphasis, AvR) 
What distinguishes prayer from other types of saying is that it accompanies certain actions, rituals, movements. In other words, prayer is a linguistic gesture accompanied by other, non-linguistic gestures. But what does it mean that the poetic saying of prayer apparently cannot do without a certain ritualistic entourage in order to be prayer? In short, what is the function of this entourage?

The answer to this question demands a reconsideration of Nancy's analysis of the relationship between myth, religion and poetry as proposed in 'Prière démythifiée'. As we have seen, according to Nancy prayer is a demythologisation of Christianity, since it testifies to the absence of God. In addressing this absence, prayer serves as a model for the intertwinement of proximity and distance, of touching and non-touching that characterises the Christian attitude towards the divine. As Nancy indicated, this delicate and paradoxical intertwinement can only be preserved within a saying that is emptied of every representational and thus mythological content. Nevertheless, this emptied saying turns out to take place within the well-fixed and meaningful context of a specific place, a specific position of the body, a closing or rather lifting of the eyes. Given this ritualistic entourage, could we perhaps not say that the opening towards a beyond that exemplifies demythologised praying can only take place within a certain closed form, i.e. within a codified, pre-structured topos that is isolated from its context? In other words, could it be that the poetic saying of prayer, a saying that is an opening towards and of being, necessarily takes place within a realm that is perhaps indeed deprived of its referential meaning, but is still mythological in the sense that it is a structuring, an emplotment of actions?

Although I have to leave aside the question to what extent art or poetry would also demand a ritualistic entourage, I would argue that prayer can only be affirmed as such because of this entourage. No matter how emptied its meaning may be, in order to be affirmed as prayer, the poetic verse has to meet certain specific conditions. One could therefore say that the poetic making or opening that is prayer first of all needs to be made itself. In order to be an opening gesture towards the world, or meaning as such, as Nancy indicates, prayer at the same time demands a closing, or fixation, of this meaning. One can wonder whether Nancy's ontologisation of poetry leaves room for such a thought. As I have tried to show, prayer is perhaps not only emptied, non-referential and performative speech, but a kind of speech that can indeed only be performative within a pre-figured context of certain rituals. As we saw, it is true that Nancy's demythologisation of prayer should not be understood as the abolishing of mythology by logos, but rather as an auto-deconstruction of mythology itself. 
However, one could still ask whether prayer - or more generally an addressing of that which is absent - does not just call for a demythologisation, but also - in a mutually constitutive way - for a mythologisation of speech. Perhaps it is ultimately not so much through a logos without muthos that demythologised prayer can be articulated, but rather through a logos as muthos.

Aukje van Rooden (1979) is a PhD candidate, Department of Philosophy and Language and Culture Studies, Tilburg University, the Netherlands. Her research examines the relationship between mythology, politics and literature in contemporary society, from both philosophical and literary theory perspectives. She is also a visiting researcher at Facultaire Unie Filosofie, Theologie \& Religiewetenschappen, Radboud University, Nijmegen, the Netherlands and co-editor of the volume Retreating Religion: Deconstructing Christianity with Jean-Luc Nancy. Major reference points in her research are the works of the early Romantics and those of Jean-Luc Nancy. Address: Vigiliusstraat 15; 5046 KD Tilburg; Nederland; email: a.vanrooden@uvt.nl 